\title{
MEMPERBAIKI AKHLAK PESERTA DIDIK MELALUI TEKNIK MIND MAPPING
}

\author{
Ayshah Nur Fatimah \\ Program Studi Pendidikan Agama Islam, Pascasarjana IAIN Surakarta \\ Email: ayshahnurfatimah@gmail.com
}

\begin{abstract}
Abstrak
Akhlak menempati posisi yang sangat penting dalam Islam, sehingga setiap aspek dari ajaran agama Islam ini selalu berorientasi pada penanaman dan pembinaan akhlak yang mulia. Penelitian ini bertujuan untuk mengetahui bagaimana memperbaiki akhlak melalui teknik mind mapping dalam bimbingan konseling studi kasus di SMP Negeri 1 Eromoko. Penelitian ini merupakan penelitian kualitatif dengan pendekatan studi kasus. Teknik pengumpulan data yang digunakan adalah observasi, wawancara, dan dokumentasi. Sedangkan teknik keabsahan data menggunakan triangulasi data dan ketekunan pengamatan, teknik analisis data yang digunakan adalah pendekatan deskriptif kualitatif. Hasil penelitian ini menjelaskan bahwa memperbaiki akhlak melalui teknik mind mapping dalam bimbingan konseling studi kasus di SMP Negeri 1 Eromoko Wonogiri Tahun Ajaran 2018/2019 dilakukan dengan langkah sebagai berikut: Pertama salam, menguji kejujuran, menjelaskan permasalahan peserta didik, menjadikan satu bagian peserta didik yang berakhlak kurang baik menjelaskan mind mapping, membagi kelompok, membuat mind mapping berdasarkan akhlak buruk yang dilakukan, membuat fokus di bagian tengah, membuat cabang-cabang yang dihubungkan ke pusat, mengisi cabang-cabang dengan tindakan yang akan dilakukan untuk memperbaiki akhlak, menggunakan kata kunci, warna, dan gambar, garis yang mudah diingat kemudian evaluasi dan pengamatan.
\end{abstract}

Kata Kunci : Memperbaiki Akhlak, Mind Mapping, Bimbingan Konseling

\section{Abstract}

Morals occupy a very important position in Islam so that every aspect of Islamic teachings is always oriented towards cultivating and building noble morals. This study aims to find out how to improve morals through mind mapping technique in the counseling guidance in SMP N 1 Eromoko. This research used the qualitative method with a case study approach. The techniques of collecting data used by the researcher were observation, interview, and documentation. While the data validity technique used data triangulation and persistence of observation, the data analysis technique used a descriptive qualitative approach. The result of this study explained that improving morals through mind mapping techniques in counseling guidance in SMPN 1 Eromoko, Wonogiri in the Academic Year 2018/2019 was carried out with these following steps: greeting, testing the honesty, explaining the students' problem, grouping students who had inadequate behavior, explaining the mind mapping, dividing groups, drawing a mind mapping based on students' inadequate moral, focusing in the center, making branches that connected to the center, filling the branches with actions which taken to improve morals, using the keyword, color, dan picture, line which was easy to remember, then evaluating and observing.

Key Words : improving morals, mind mapping, Counseling

\section{PENDAHULUAN}

Akhlak menempati posisi yang sangat penting dalam Islam, sehingga setiap aspek dari ajaran agama Islam ini selalu berorientasi pada penanaman dan pembinaan akhlak yang mulia, yang disebut akhlak al-karimah. Akhlak juga menjadi salah satu ukuran keimanan seseorang. Jika seseorang memiliki akhlak yang baik maka derajatnya akan meningkat, namun sebaliknya jika akhlaknya buruk maka akan menurunkan derajatnya. Dalam Islam akhlak adalah suatu perilaku yang menghubungkan antara Allah SWT dan makhluknya. Akhlak salah satu inti dari ajaran 
Rasulullah SAW. Akhlak merupakan hal ihwal atau sifat yang tertanam dalam jiwa manusia, sehingga akan muncul secara spontan bilamana diperlukan, tanpa memerlukan pemikiran atau pertimbangan terlebih dahulu, dan bukan merupakan dari luar [1].

Selain itu akhlak juga merupakan sifat yang melekat pada diri seseorang dan menjadi identitasnya atau sifat yang telah dibiasakan, ditabiatkan, didarah dagingkan, sehingga menjadi kebiasaan dan mudah dilaksanakan dan dapat dirasakan manfaatnya. Jadi akhlak akan memberikan penilaian terhadap sesuatu perbuatan dan menyatakan baik atau buruk [2].

Akhlak hal penting dalam kehidupan masyarakat, apalagi di era globalisasi ini. Tidak adanya akhlak dalam tata kehidupan masyarakat akan menyebabkan hancurnya masyarakat itu sendiri. Hal ini dapat diamati pada kondisi yang ada di negeri ini. Atau dengan kata lain, bangsa Indonesia saat ini bukan saja krisis ekonomi dan krisis kepercayaan akan tetapi juga krisis akhlak di masyarakat, sekolah dan dalam keluarga.

Akhir-akhir ini banyak terjadi berbagai kejadian yang menunjukkan akhlak yang buruk di kalangan siswa ataupun remaja di Kudus yang dianggap menyimpang dan mengganggu kenyamanan masyarakat yang antara lain tawuran, pengeroyokan, dan pelanggaran lalu lintas, minumminuman keras, perjudian, kriminalitas, merusak fasilitas umum dan menonton video porno [3]. Selain di Kudus, permasalahan akhlak yang buruk juga terjadi di Desa Wonorejo dimana banyak terjadi perkelahian, pemakaian miras dan narkoba, pembunuhan, pencurian, membolos sekolah, tidak mengerjakan PR, bermain HP saat pelajaran, merokok di lingkungan sekolah dan memakai atribut sekolah yang tidak sesuai standar [4].
Untuk mengatasi hal tersebut biasanya yang dilakukan oleh pihak sekolah yaitu dengan memberikan nasehat ataupun pembinaan dengan Guru BK dengan memanggil siswa yang bersangkutan dan jika masih terulang maka akan memanggil kedua orang tua yang bersangkutan, bahkan ada sekolah yang langsung mengeluarkan siswa tersebut. Dalam pemberian sanksi dilakukan secara bertahap [5]. Melihat beberapa berita yang ada dalam media masa ataupun siaran radio dan televisi, akhlak anak di era sekarang sangat memprihatinkan dan menunjukkan akhlak yang kurang baik.

Seperti telah diketahui masalah akhlak di era sekarang itu sudah menjadi suatu masalah yang sangat mendasar bagi setiap pribadi muslim dalam kehidupan seharihari yang mampu mewarnai segala sikap dan perilakunya baik ketika berhubungan dengan manusia maupun ketika berhubungan dengan Allah. Seperti yang terjadi di SMP Negeri 1 Eromoko Wonogiri masih ditemukan peserta didik yang bertutur kata kotor, berkelahi, membuat gaduh kelas, mencela orang dan tidak menghormati guru. Dalam suatu lembaga pendidikan untuk menangani hal tersebut adalah dengan layanan bimbingan dan konseling, pemberiaan nasehat oleh wali kelas dan pembinaan oleh Guru PAI. Tujuan utama dalam dunia pendidikan adalah pembentukan akhlak yang sanggup menghasilkan orang-orang bermoral, jiwa yang bersih, kemauan yang keras, cita-cita yang benar dan akhlak yang tinggi melalui proses pembinaan secara bertahap.

Pada setiap sekolah pasti mempunyai Guru Bimbingan dan Konseling yang mempunyai tugas untuk membentuk akhlak siswa yang lebih baik. Terkait dengan hal tersebut, di masa sekarang ini Guru BK (Bimbingan Konseling) mempunyai peranan yang sangat penting dalam meningkatkan kualitas siswanya 
yang berhubungan dengan akhlak para siswa. Selain itu, bimbingan konseling juga bertujuan membantu anak memahami diri sendiri, baik sebagai makhluk tuhan maupun makhluk sosial. Sebab guru bimbingan dan konseling mempunyai banyak layanan baik itu layanan yang sifatnya individu maupun kelompok. Bimbingan dan konseling mempunyai bebarapa jenis layanan yaitu layanan orientasi, layanan informasi, layanan penempatan dan penyaluran, layanan bimbingan belajar, layanan konseling perorangan, dan layanan bimbingan dan konseling kelompok [6].

SMP Negeri 1 Eromoko Wonogiri juga melakukan berbagai layanan bimbingan konseling, salah satu layanan yang digunakan layanan bimbingan kelompok. Layanan bimbingan kelompok itu suatu cara memberikan bantuan kepada peserta didik melalui kegiatan kelompok [7]. Masalah yang ditangani melalui layanan bimbingan kelompok salah satunya adalah masalah akhlak. Di SMP Negeri 1 Eromoko masih ditemukan peserta didik yang memiliki akhlak yang kurang baik, antara lain masih sering berkata kotor, mencela orang, berkelahi di kelas, membuat gaduh kelas, dan tidak menghormati guru (Wawancara dengan Ibu Siti Fathonah pada hari Senin 21 Mei 2018).

Di SMP Negeri 1 Eromoko Wonogiri hal tersebut tidak lepas dari perhatian lebih dari guru khususnya Guru BK untuk membimbing dan mengarahkan perkembangan kemampuan peserta didik secara optimal untuk berkreasi, mandiri, bertanggung jawab dan berakhlak mulia. Pelaksanaan layanan bimbingan kelompok di SMP Negeri 1 Eromoko Wonogiri sebelumnya menggunakan metode ceramah, guru memberikan nasehatnasehat dan klien hanya mendengarkan. Kemudian sekolah mengembangkan teknik layanan bimbingan kelompoknya dengan menerapkan teknik yang santai, kreatif, menarik tapi serius dengan menggunakan teknik mind mapping. Hal tersebut sangatlah berbeda dengan penelitian mengenai pembinaan akhlak yang dilakukan melalui metode keteladanan dan pembiasaan [8], sedangkan penelitian yang akan dikaji yaitu memperbaiki akhlak melalui teknik mind mapping. Adapun persamaan penelitian yang dikaji dengan penelitian tersebut yaitu sama-sama berkaitan dengan pembinaan akhlak ataupun memperbaiki akhlak siswa.

Teknik Mind Mapping termasuk teknik yang tidak membosankan, karena teknik ini bisa digunakan untuk mendapatkan berbagai macam alternatif jawaban dari persoalan pada suatu materi pelajaran [9]. Teknik mind mapping yang dilakukan dalam layanan bimbingan konseling ini akan membantu peserta didik untuk mengingat tindakan apa yang akan dilakukan untuk memperbaiki akhlak yang kurang baik yang mereka lakukan. Dimana peserta didik akan membuat cabangcabang peta pikiran, yang berisikan tindakan-tindakan untuk memperbaiki akhlak yang setiap individunya mempunyai tindakan yang berbeda-beda, tergantung akhlak kurang baik yang individu lakukan. Teknik mind mapping ini akan membantu memperbaiki akhlak peserta didik dengan peta pikiran yang mereka buat [10]. Mind mapping membantu mengembangkan kreativitas dalam menyusun ide-ide pokok yang mudah dipahami oleh peserta didik. Teknik layanan bimbingan kelompok yang digunakan sebelumnya untuk memperbaiki akhlak mencapai presentase sebesar 50\% peserta didik yang berakhlak baik dari semua peserta didik yang melakukam layanan bimbingan kelompok dan kemudian setelah teknik tersebut dikembangkan presentasenya menjadi $70 \%$ peserta didik yang berakhlak baik dari 
semua peserta didik yang melakukan layanan bimbingan kelompok melalui teknik mind mapping (Wawancara dengan Ibu Nurul Aslikhah pada hari Senin 16 Juli 2018).

SMP Negeri 1 Eromoko Wonogiri menerapkan teknik mind mapping untuk memperbaiki akhlak sejak 5 tahun yang lalu. Dalam pelaksanaan dilakukan oleh Guru BK yang bekerja sama dengan Guru Pendidikan Agama Islam (Wawancara dengan Ibu Dra. Siti Fatonah FJ pada hari Minggu 20 Mei 2018). Layanan bimbingan kelompok dilaksanakan di jam bimbingan konseling dan di luar jam bimbingan konseling yang membutuhkan waktu sekitar 2 minggu untuk memantau akhlak siswa selanjutnya. Dimana sebelum melakukan pelaksanaan layanan bimbingan kelompok melalui teknik mind mapping, Guru BK mengumpulkan semua peserta didik yang memiliki akhlak yang buruk kemudian menguji tingkat kejujuran mereka dalam berakhlak, kemudian menjelaskan konsep pembuatan mind mapping untuk memperbaiki akhlak, setelah itu Guru Pendidikan Agama Islam dan Guru BK mengevaluasi pembuatan mind mapping peserta didik (Wawancara dengan Ibu Nurul Aslikhah pada hari Senin 16 Juli 2018).

Berdasarkan permasalahan di atas, tujuan dari penelitian ini yaitu untuk mengetahui bagaimana memperbaiki akhlak melalui teknik mind mapping, sehingga dengan adanya penelitian ini akan menjadi acuan guru-guru dalam mengatasi ataupun memperbaiki akhlak siswa di sekolah.

\section{METODE}

Penelitian ini merupakan penelitian kualitatif dengan pendekatan studi kasus. Penelitian kualitatif adalah prosedur penelitian yang menghasilkan data diskriptif berupa kata-kata tertulis atau lisan dari orang-orang dan perilaku yang dapat diamati [11]. Penelitian ini dilaksanakan di SMP Negeri 1 Eromoko Wonogiri, pada bulan Juni-Desember 2018. Subjek penelitian adalah Guru BK dan Guru PAI, sedangkan informan penelitian adalah kepala sekolah, teman sejawat Guru BK dan Guru PAI dan peserta didik Siswa kelas VIII B di SMP Negeri 1 Eromoko Wonogiri. Teknik pengumpulan data yang digunakan adalah observasi, wawancara, dan dokumentasi. Sedangkan teknik keabsahan data menggunakan triangulasi data dan ketekunan pengamatan. Teknik analisis data yang digunakan adalah pendekatan deskriptif kualitatif.

\section{HASIL DAN PEMBAHASAN}

Hasil penelitian terhadap siswa kelas VIII B SMP Negeri 1 Eromoko dengan jumlah siswa adalah 30 siswa. Adapun rinciannya dapat dilihat pada Tabel 1 sebagai berikut:

Tabel 1. Jumlah Peserta Didik Kelas VIII B

\begin{tabular}{cc}
\hline Siswa laki & Siswa perempuan \\
\hline 17 & 13 \\
\hline \multicolumn{3}{c}{$\begin{array}{l}\text { Sumber : Dokumentasi Data Siswa Kelas } \\
\text { VIII B SMP N 1 EROMOKO 2018 }\end{array}$}
\end{tabular}

Penelitian dilakukan di kelas VIII B karena merupakan kelas paling banyak terdapat peserta didiknya yang melakukan akhlak tidak baik yaitu sejumlah 10-15 anak (Dokumentasi Anecdote Record pada tanggal 3 - 8 Agustus 2018)

Hasil penelitian ini menunjukkan bahwa memperbaiki akhlak melalui teknik mind mapping dalam bimbingan konseling siswa kelas VIII B SMP Negeri 1 Eromoko Wonogiri adalah dimulai dengan salam, menguji kejujuran siswa, menyampaikan pelanggaran siswa, mengumpulkan semua peserta didik yang melakukan akhlak yang kurang baik, menjelaskan pembuatan mind mapping dan membagi peserta didik menjadi beberapa kelompok. Kemudian guru meminta peserta didik untuk membuat mind mapping dan setelah semua 
selesai, satu persatu siswa diminta untuk menjelaskan dari mind mapping yang telah dibuat dan guru mengevaluasinya. Jika dalam pelaksanaan tidak mencukupi maka dilanjutkan di luar jam pembelajaran, yaitu ketika pulang sekolah atau jam istirahat. Dalam proses pembuatan diawali dengan membuat fokus di tengah-tengah kertas dan kemudian membuat cabang yang dihubungkan ke pusat. Cabang-cabang tersebut nanti diisi dengan tindakan yang akan dilakukan oleh peserta didik. Dalam membuat tindakan ditulis dengan menggunakan huruf besar, menggunakan warna-warna dan gambar untuk memudahkan dalam mengingat.

Setelah peserta didik selesai membuat mind mapping berdasarkan imajinasinya dan pelanggaran mereka masing-masing, kemudian peserta didik menjelaskan apa yang mereka buat kepada Ibu Nurul Aslikhah dan Ibu Siti Fathonah satu persatu. Kemudian setelah itu Ibu Siti Fathonah dan Ibu Nurul Aslikhah akan mengevaluasi mind mapping yang telah dibuatnya. Setelah itu Ibu Nurul Aslikhah dan Ibu Siti Fathonah memantau selama 2 minggu ke depan mengenai akhlak peserta didiknya tersebut. Jika ada siswa yang melakukan akhlak yang kurang baik lagi maka Ibu Nurul Aslikhah atau Ibu Siti Fathonah akan memanggil peserta didik tersebut kembali sambil membawa mind mapping yang telah dibuatnya. Kemudian meminta siswa menambahkan tindakan untuk memperbaiki akhlaknya lagi. Adapun gambar mind mapping siswa kelas VIII B dalam memperbaiki akhlak adalah sebagai berikut :

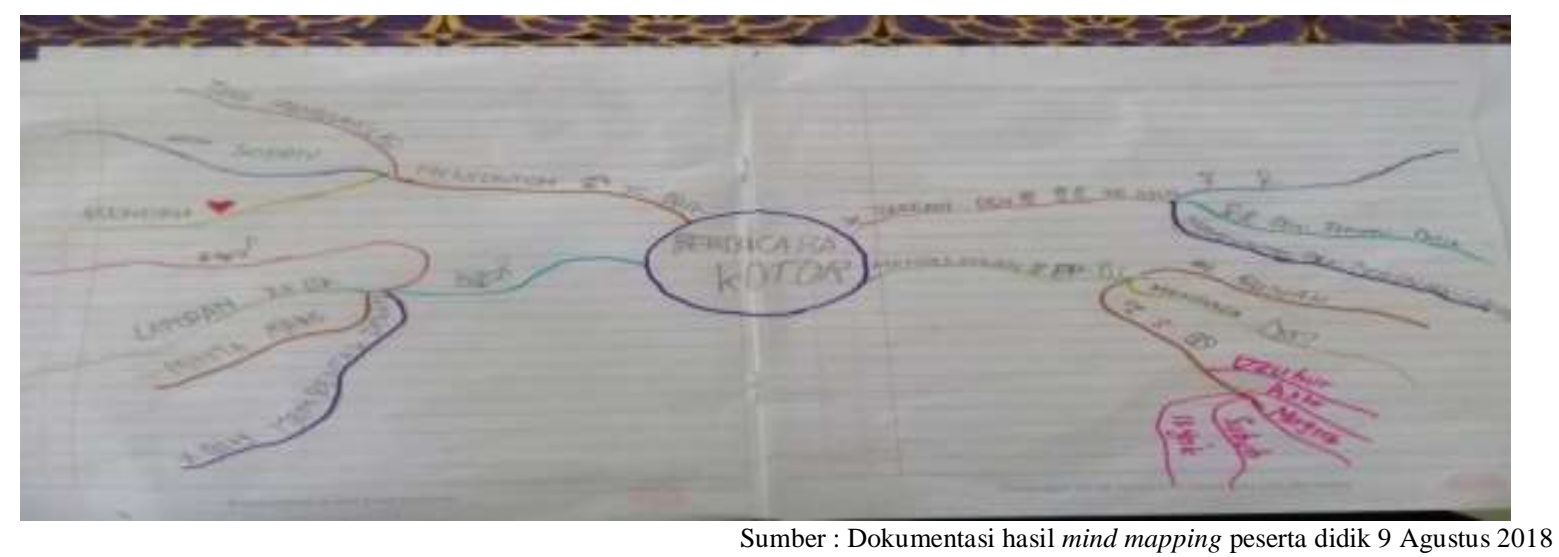

Gambar 1. Mind Mapping Siswa Kelas VIII B Memperbaiki Akhlak Berbicara Kotor

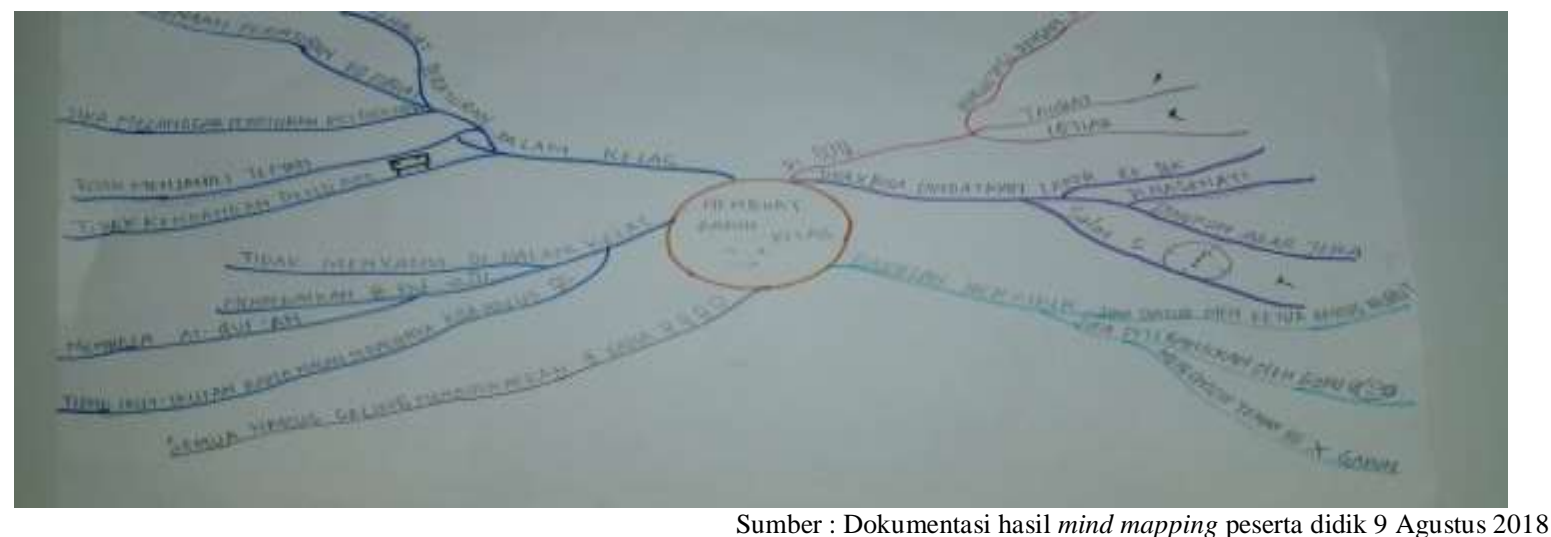

Gambar 2. Mind Mapping Siswa Kelas VIII B Memperbaiki Akhlak Membuat Gaduh Kelas 
Jika dilihat dari pelaksanaannya terdapat perbedaan antara teori dengan pelaksanaan yang dilakukan di kelas yaitu ada satu tahapan yang terlewati di mana guru tidak membagi peserta didik yang melakukan akhlak yang kurang baik menjadi beberapa kelompok, mind mapping yang dibuat siswa masih ada yang terbalik dalam penulisannya, mind mapping yang dibuat siswa, setiap akar cabangnya menggunakan warna yang sama sedangkan dalam teori menggunakan warna-warna yang berbeda setiap akar cabangnya. Jika dilihat pelaksanaan layanan bimbingan kelompok melalui teknik mind mapping dalam bimbingan konseling untuk memperbaiki akhlak, pelaksanaannya masih tercampur dengan siswa yang memiliki akhlak yang baik. Sedangkan dalam bimbingan konseling kerahasiaan klien itu harus terjaga. Dalam pelaksanaannya guru terlalu cepat memberikan layanan bimbingan kelompok tanpa menunggu keterbukaan dari peserta didik terlebih dahulu.

Hasil dari penelitian memperbaiki akhlak melalui teknik mind mapping dalam bimbingan konseling siswa kelas VIII B SMP Negeri 1 Eromoko tahun ajaran 2018/2019, menurut peneliti sudah baik dan mencapai tujuan yang telah diharapkan. Di mana peserta didik mampu memperbaiki akhlaknya melalui mind mapping yang mereka buat sendiri dalam pelaksanaan layanan bimbingan kelompok. Pelaksanaan layanan bimbingan kelompok melalui teknik mind mapping dalam bimbingan konseling untuk memperbaiki sangat berpengaruh dalam memperbaiki akhlak peserta didik, peserta didik lebih ingat terhadap tindakan apa yang harus dilakukan untuk memperbaiki akhlaknya yang mereka buat sendiri dalam cabang-cabang akar mind mapping. Namun hanya saja dalam pelaksanaannya guru terlalu cepat memberikan pelayanan tanpa menunggu keterbukaan dari peserta didik terlebih dahulu dan pelaksanaannya masih dijadikan satu untuk penyelesaian semua akhlak buruk yang dilakukan oleh peserta didik, padahal akhlak yang mereka lakukan berbeda-beda.

Berdasarkan uraian di atas, dapat dikatakan bahwa teknik mind mapping sangat membantu guru dalam memperbaiki akhlak peserta didik. Pernyataan ini didukung oleh penelitian terdahulu yang menyatakan bahwa metode mind mapping dapat meningkatkan perilaku terpuji (taat, ikhlas, khauf dan taubat). Ini berarti bahwa metode mind mapping sangat membantu siswa untuk berperilaku baik [12].

\section{SIMPULAN}

Berdasarkan hasil penelitian dan pembahasan yang telah disajikan, maka dapat disimpulkan bahwa memperbaiki akhlak melalui teknik mind mapping dalam bimbingan konseling di SMP Negeri 1 Eromoko Wonogiri adalah pertama salam, menguji kejujuran, menjelaskan permasalahan peserta didik, menjadikan satu bagian peserta didik yang berakhlak kurang baik menjelaskan mind mapping, membagi kelompok, membuat mind mapping berdasarkan akhlak buruk yang dilakukan, membuat fokus di bagian tengah, membuat cabang-cabang yang dihubungkan ke pusat, mengisi cabangcabang dengan tindakan yang akan dilakukan untuk memperbaiki akhlak, menggunakan kata kunci, warna, dan gambar, garis yang mudah diingat kemudian evaluasi dan pengamatan.

\section{DAFTAR PUSTAKA}

[1] Subahri. "Aktualisasi Akhlak dalam Pendidikan”. J. Stud. Islam, vol. 2, no. 2, p. 170, 2015.

[2] A. Nata. Pemikiran Pendidikan Islam dan Barat. Jakarta: PT Raja Grafindo Persada, 2012.

[3] I. N. Shanty, Suyahmo dan S. Sumarto. "Faktor Penyebab Kenakalan Remaja pada Anak 
Keluarga Buruh Pabrik Rokok Djarum di Kudus". Unnes Civic Education Journal, vol. 1, no. 2 pp. $1-11,2015$.

[4] E. Suhartini dan S. Ariyanik. "Fenomena Kenakalan Remaja di Desa Wonorejo Kabupaten Situbondo". Jurnal Entitas Sosiologi (JES), vol. 1, no. 2, pp. 1-11, 2012.

[5] A. Shole, D. Endah, dan S. Adhi. "Bentuk Ketegasan dalam Proses Pembelajaran 'Dampak Sanksi terhadap Kedisiplinan Siswa di SD Kaliwiru Semarang'". Journal of Primary and Children's Education (JANACITTA), vol. 2, no. 2, pp. 111, 2019.

[6] Hallen. Bimbingan dan Konseling. Jakarta: Quantum Teaching, 2005.

[7] Tohirin. Bimbingan dan Konseling di Sekolah dan Madrasah. Jakarta: PT Raja Grafindo Persada, 2013.

[8] S. Manan. "Pembinaan Akhlak Mulia Melalui Keteladanan dan
Pembiasaan". Jurnal Pendidikan Agama Islam-Ta'lim, vol. 15, no. 1,pp. 49-65 2017.

[9] S. Hamid. Metode Edutainment. Yogyakarta, 2011.

[10] A. Z. L. Heri Hidayat, Heni Mulyani, Ajeng Siti Fatimah, dan Ammalia Sholihat. "Penerapan Metode Mind Mapping untuk Meningkatkan Kreativitas pada Pembelajaran Pendidikan Kewarganegaraan". J. Pendidik., vol. 21, no. 1, pp. 38-50, 2020.

[11] L. J. Moleong. Metodologi Penelitian Kualitatif. Yogyakarta: Rosdakarya: 2005.

[12] I. A. Hamid dan A. Yudiawan. "Model Pembelajaran Mind Mapping Kelas VII pada mata pelajaran Akidah Akhlak di MTs Az- Zikra Kota Sorong”. Al-Fikr Jurnal Pendidikan Islam, vol. 4, no. 1, pp. 6-10, 2018. 